\title{
Correction to: Population Trends and Fire Prevention in Merseyside UK
}

\author{
M. Taylor*, Department of Computer Science, Liverpool John Moores \\ University, Byrom Street, Liverpool L3 3AF, England \\ D. Appleton, G. Oakford and J. Fielding, Merseyside Fire and Rescue Service, \\ Bridle Road, Liverpool L30 4YD, England
}

Accepted: 13 August 2021/Published online: 31 August 2021

\section{Correction to: Fire Technology, 57, $1783-1802,2021$, https://doi.org/10.1007/s1 0694-020-01083-w}

The article "Population Trends and Fire Prevention in Merseyside UK", written by M. Taylor, D. Appleton, G. Oakford and J. Fielding, was originally published electronically on the publisher's internet portal on 03 February 2021 without open access. With the author(s)' decision to opt for Open Choice the copyright of the article changed on 13 August 2021 to (C) The Author(s) 2021 and the article is forthwith distributed under a Creative Commons Attribution 4.0 International License, which permits use, sharing, adaptation, distribution and reproduction in any medium or format, as long as you give appropriate credit to the original author(s) and the source, provide a link to the Creative Commons licence, and indicate if changes were made. The images or other third party material in this article are included in the article's Creative Commons licence, unless indicated otherwise in a credit line to the material. If material is not included in the article's Creative Commons licence and your intended use is not permitted by statutory regulation or exceeds the permitted use, you will need to obtain permission directly from the copyright holder. To view a copy of this licence, visit http://creat ivecommons.org/licenses/ by/4.0.

The original article has been corrected.

The original article can be found online at https://doi.org/10.1007/s10694-020-01083-w.

*Correspondence should be addressed to: M. Taylor, E-mail: m.j.taylor@ljmu.ac.uk 